\title{
An Action Research Report on Promoting Learners' Motivation in College English Intensive Reading Course in China
}

\author{
$\mathrm{Xiao} \mathrm{Fu}$ \\ College of Foreign Languages, Chongqing Jiaotong University, China
}

\begin{abstract}
This study is to examine whether the implementation of motivational strategies in an intensive reading class has a positive effect, whether it helps activate their enthusiasm for and ease their anxiety of participation in language class activities, and whether it is helpful to their improvement of English proficiency. The research questions to be addressed in the study are: 1. what's the motivation of my students in English reading? 1) Do my students have stronger/weaker integrative motivation than instrumental motivation? 2) How do the integrative and instrumental motivation relate to the students' reading ability? 2. Can students be motivated to read, by applying motivational strategies in EFL setting? If yes, in what way can I make it as effective as possible? 1) what makes a task more interesting? 2) What causes a student to be more engaged by one project than another? 3) How can teachers design work that will keep students' attention at the same time it draws them more deeply into the process of learning? The whole process of the research was divided into4 cycles of planning, implementing and reflecting on progress. Classroom observation, teacher's diary, questionnaire and informal interview were used as instruments to collect data for reflection throughout the research. The final results show that, motivational strategies do have some positive effects on improving the present passive situation in my English classroom. However, there are some problems arising from the action research.
\end{abstract}

Index Terms - motivation, action research, English as a Foreign Language (EFL) learner

\section{INTRODUCTION}

Nowadays, educational reform in China is trying to improve the education situation. In the last few years, some researchers in China did some researches on motivation in Foreign language learning, as some study on social - psychological factors and language learning, Wen (2001) did a case study on a successful and an unsuccessful English learner. Wen tried to find what are the different motivation among them. Even though there have been a lot of education-oriented publications providing taxonomies of classroom-specific motives, they fall short of offering an efficient guide to practitioners.

\section{ReSEARCH Methodology}

\section{A. Instruments}

Classroom observation, reflective journal, informal interviews, and questionnaires were used as instruments to collect data in my research. Appendix A provides the details of the instrument sheets.

\section{B. The Sample}

Subjects for the whole study were 58 college students majoring in computer science. This class was randomly selected from one of my teaching classes for the semester.

All the participants were first-year Non-English majors from the same class who had attended the university for half a year, aged from 18 to 20 .

Among the sample population 24 were females and 34 were males. They had learned English for at least six years before their enrolment in this university. The students have different personalities and different proficiency levels in English learning.

\section{Procedure Details}

\section{Cycle 1: Creating the Basic Motivational Conditions}

Week 1-4

In the first week, I introduced myself and the requirements of the Intensive English Reading course. I also explained the aims and process of the research which I was doing with my students. My students' support and cooperation made me go on with the research. I found that personalizing really helped to increase the students' interest levels. Carl Rogers claimed that learning would be much more effective when the facilitator does not hide behind a façade. Students showed curiosity and were inquisitive. I think that was because I gave them the chance they wanted to know more about 
me and my life outside the classroom. It is a personal decision how much of yourself you want to give away and share with your students.

Peer pressure may be one of the factors that cause them are not to be actively involved in the class. Then, I encouraged my students to do self-introduction. I encouraged them to cherish this chance. I told them as a large class, few chances would be gained if they didn't catch it in time. Some students did it as volunteers. Other students also tried to make an attempt. They seemed to be pleased to let others know themselves and cherished this chance to show themselves in public. From their self-introductions, I got to know their receptive age, interests, and hometown; also, in some degree, their personalities. Getting to know each other was the first activity I took to generate the basic motivational conditions.

In the second week, I asked them to write a composition: why I read in English? I told them it was a good way for us to reach out to. And I explained it was not extra homework, they could write either in English or Chinese. I told them English is such a beautiful language; I didn't want them to just learn it. I also wanted to let them think about why they learn it. It is a reflective work for them. Via the students' compositions, I found instrument motivation is much stronger than integrative motivation among my students. Most students said they learn English to pass examinations, future work, a better job, going aboard... Few students said they enjoy learning English. But I have found all students agreed that English is very import to them, though some of them said they lost interest in learning English. I checked their scores in the fist English reading proficiency test, of those who said they enjoy learning English, and found that most of them got higher scores than other students.

Here is the result from students' composition: "Why I read English". The following are the students' statements:

1. By learning to read in English, I hope I will be able to read English novels, English newspapers and/or magazines. $(5 \%)$.

2. Learning to read in English is important in that we need to cope with internationalisation. (2\%)

3. It is fun to read in English. (6.9\%)

4. By being able to read in English, I hope to understand more deeply about lifestyles and cultures of English speaking countries. $(8.2 \%)$

5. Reading in English is important because it will make me a more knowledgeable person. (4.8\%)

6. I am learning to read in English merely because I would like to get good grades in examinations, like CET - 4. $(30.5 \%)$

7. I am taking a reading class merely because it is a required subject. (18.9\%)

8. Learning to reading in English is important because it will be conducive to my general education. (35.6\%)

9. I would not voluntarily read in English unless it is required as homework or assignment. (42.2\%)

10. I am learning to read in English because I might study abroad in the future. $(6 \%)$

Via students' composition: "Why I read in English?", 87.8\% students said they have strong motivation in English reading, others said not. $20.3 \%$ students said they read for enjoyment; $33.3 \%$ students said they read English for gaining information; $23.8 \%$ students said they read to pass the CET or other English examinations; $36.5 \%$ students said they read for their future or career.

For further understanding of their motivation, I did a general surveys among them. The questions I adopted from Wallace (1998), Action Research for Language Teachers. I asked them "How would you describe your motivation?" $78.8 \%$ students said they have high motivation in English learning.

$15.3 \%$ students said they don't want to learn English at all. 6\% students said they don't know. In response to my question: "What would you say are the things that have affected your motivation over your period of study?" $37.9 \%$ students said the materials were not attractive enough. $28.8 \%$ students said they didn't feel interested in the teacher's way of teaching.

Students' feedback proved my hypothesize: yes, students have strong motivation to read English, though most of the motivation inclined to instrumental motivation. But it still remained a puzzle: How does the integrative and instrumental motivation relate to the students' reading ability?

Also, from the survey, I also asked them: "What would you say are the things that have affected your motivation over your period of study? Teachers/text books/fellow students/ something in you?" I heard the opinions from my students and found a problem I would plan in my second cycle: Students felt the materials were not attractive enough. I plan to add some interesting and relevant materials for them in the second cycle-Generating students motivation.

At the end of the first four weeks, I reflected about the research. The relationship between teacher and students and peer relationship were improved greatly in the first cycle. But Students' feedback collected at the end of this cycle showed that many students complained the communication between the teacher and students was so poor. As one of the students wrote, "You leave the classroom after the class is over, and we cannot find you until next class." Yes, I had to admit the reality that I didn't have many chances to communicate with students. It reminded me that one student telephoned me and told me that she was so depressed because she had an impediment in speech. She was nervous when speaking with people in daily life, let alone in English class. That day, I had a talk with her. The talk helped her built up her self-confidence. I noticed that she became more active and happier from then on.

The students' feedback and the above-mentioned matter made me think about the necessity of enhancing the communication between the students and me. I haven't enough time and chance to be with the students. I thought about 
using e-mails from cycle two.

Also, I found my students did have motivation to learn English and they regarded English as one of their most important subjects. They really wanted to learn English well. They felt passive and demotivated; one of the reasons was concerning my teaching style and also the limited class time and abundance of text materials, I usually use instruction method for grammar and language points and so. Students got few chances to practice. In the second cycle, to help students involve participate actively and was one of the most important actions I should modify.

Another problem sounded from one of my students: Miss Liqing, Zhan. She is a student who has the strong motivation to learn English. But she never answered my questions in class by volunteering herself. She said she really wanted to learn English well and she made great efforts to do so. Here are her difficulties: 1. Teacher speaks completely English in class and she couldn't understand it all. 2. She has no chance to practice her oral English. I told her there was an English corner every Thursday but she seemed to always miss it because of the meetings. She wanted to get more chances to practice. I suggested her to talk with her roommates for half an hour every day in English. 3. She said even though she prepared for English lesson very well, she dare not volunteer at any stage.

However she said it was very good that I always praised those students who answering questions and she thought I was very kind and patient.

How can I maintain and protect those students' motivation? They work very hard but they thought they are poor at English; they want to answer my questions but they dare not; they have good learning habits, yet how can I get them involved in classroom activities?

\section{Cycle 2: Generating Students' Motivation}

\section{Week 5---8}

To find answers to those problems which appeared in cycle I, Questionnaire 1 was distributed to 56 students, 53 were returned to be collected.

The result showed that the students thought the teacher was enthusiastic about her teaching and prepared the teaching materials carefully but they generally felt that the class was boring, and both the texts and teacher's style of presentation were not interesting. In addition, they admitted that they needed training in reading strategies and skills.

In Part II and Part III of the questionnaire, the students explained the reasons why they were not active and de-motivated in class, and they also gave some suggestions on how to make the class more interesting so that they can maintain and protect their motivation in the class. The following are the reasons they gave for being passive in class:

1.They cannot follow the teacher because the teaching pace is too fast.

2.The texts are boring, difficult to understand and have nothing to do with their real life.

3.The activities are not interesting.

Some of the students gave the following suggestions for improving the lessons:

1. The teacher should explain the text in more details and give more examples of how the new words can be used.

2. The teacher should organize some interesting activities to stimulate the students' interests in learning and force students to use English in class.

3 .The teacher should bring some up-to date articles for students to learn.

- Planned actions

With the problems in the first cycle in mind, the following actions were designed and acted out in the second cycle: to generate the students' motivation.

1. The traditional teacher-centered way of teaching can be changed into the learner-centered way of learning. I should give classroom back to the students. In order to help students carry out the learner-centered way of learning, some theories of reading and the critical reading strategies and skills must be taught to them. The students can use the texts in the textbook to practice these strategies and skills.

1) Acquaint the students with the following theories of reading:

A: Psycholinguistic models of reading; the bottom-up model, the top-down model and the interactive model.

B: The theory of schema.

2) The following reading strategies and skills will be introduced to the students.

A. Previewing: Learning about a text before really reading it.

B. Contextualizing: Placing a text in its historical, biographical and cultural contexts.

C. Questioning to understand and remember: Asking questions about the content,

D. Reflecting on challenges to your beliefs and values; Examining your personal responses.

E. Outlining and summarizing: Identifying the main ideas and restating them in your own words.

F. Evaluating an argument: Examining the logic of the text as well as its credibility and emotional impact.

G. Comparing and contrasting related reading: Exploring likenesses and differences between texts to understand them better.

2. Use more group activities to guide the students to learn cooperatively within each group.

3. Organize different kinds of activities to have students actively participate in classroom learning.

1) Break each text into smaller sections and ask each group to prepare only one section of the text, so that their workload can be reduced.

2) Design more questions about the texts and lead students to do more discussions in class. 
3) Set aside the first 15 minutes once each week for an activity named "News of the Week", during which each group will take turns to report to the class important national or international new from the previous week. The purpose of this activity is to arouse their interest in reading or listening to the English news and especially to practice their oral English and enlarge their vocabulary.

4) Ask each group to find and prepare at least one English article that they are interested in, and present the article to the class. The purpose of doing this is to have students take an active part in learning as well as to bring more reading materials that they felt like reading in the class.

5) Ask each group to compile an English dictionary of their own during the next semester. By doing this, students are expected to become active in learning vocabulary.

4. Change the rule of grading so that their participation and performance in the above-mentioned activities will be counted $40 \%$ of their final grade, the other $60 \%$ will be for their final exam results.

\section{Week 5:}

According to my plan, I first introduced the three psycholinguistic models of reading, namely the bottom-up model, the top-down model and the interactive model, and the theory of schema to the students. They felt these strategies were very useful and said that they would try to apply them in their reading later.

I felt very gratified that my introduction of the reading theories and strategies was well-received by the students. However, I also realize that this introduction should have been given at the beginning of this course.

\section{Week 6:}

In this week, the class was divided into 11 groups of 55 students. I then explained how each group would prepare their part of the text and how they should participate in the three activities---"News of the Week", "An article a day" and "my dictionary". I then divided the text we were about to study into 11 groups with a section to prepare. I announced that, in the next week, Group 1 would be the first group to explain the text followed by Group 2, 3,4, etc.; and that "news of the week" would start form Group 5 from the next week, and "an article a day" from Group 8 starting in the $9^{\text {th }}$ week.

The students seemed to be excited about the group work and the three activities, but some of them complained to me that this would give them too much of a burden, Though all the students agreed to have a try of this new way of learning, I still worried whether this plan could be smoothly carried out.

\section{Week 7:}

This was the first week for the activity of "news of the week". There were 5 students in Group 5, who had to broadcast news to the class for the first time. Miss Liqin Zhan was one of the members in Group 5. With my insistence, she came to the front and rushed through the news she selected from "China Daily", and then ran back to her seat without staying to answer questions from the class, I then encouraged the class to ask her questions about the news she had just read. I think this activity is really necessary because on the one hand, it can " force" the students to participate in the class activity and give a chance to those who said " I dare not but I really want to." on the other hand, it can also helped the students talk more freely in front of a large audience.

Then the time came for studying the text. Altogether four groups took their turns in explaining the part of the text assigned to them. I first asked them to summarize the main idea of their part of the text, then they analyzed the meaning and usage of some difficult words and sentences, and then they also raised some questions, thus a lot of discussion was generated. By the end of each group's work, I just summarized what we had discussed and pointed out those important points that the group failed to explain.

Students' feedback: this new style of "group learning" got the students more involved in the study of the text. But some of them said they had to prepare for it for a long time. They were afraid they could not find enough time to do required preparation.

Week8:

This week, the students in Group 6 were more relaxed than Group 5, but they still just read the news and gave no explanation to it. I then encouraged the other students to ask them questions, I also asked some students to retell the news just read by the students in Group 6, and the whole class enjoyed this activity very much.

After the NEWS activity, I spent 10 minutes explaining how they should build up their own dictionary.

As for the group learning, only Group 5 prepared their part of the text very well, Group 6 made no preparation because "they had to prepare for the news", Group 7 and 8 also did poorly because of various reasons. I had to take over their work. I felt disappointed to some extent and decided to interview some students after class.

From the unstructured interview, I learned that though they all felt group learning very interesting and useful, there were, however, two main obstacles for them to make preparations for the text. First, they needed enough time to prepare, the time I gave to them was too limited to prepare. Second, they found the text too difficult to prepare. Some of them suggested me to give up the group learning and that I resume back to the old way of teaching. They also told me that they had no time to do the other two activities ---"My Dictionary" and "An Article a Week". I decided to let the whole class take a vote on these activities in the next week.

At the end of cycle, I proposed a vote on the fate of the four activities put forward by me. As a result, only the activity of "News of the Week" was voted in, all the other three activities were voted out. However, still some students wished to go on with them. Also, one of my students went to the front and said; he found the four actives were very 
useful and did motivate him to study English. He said if we persisted with them, properly we would make progress. Students also told me that because they were used to "teacher-centered class", they now liked the style of "learner-centered" and atmosphere to learn in spite that much more time has to be spent preparing before class.

Though I felt very sad about the result, I still thought we should persist on with the learner-centered way of teaching style. However, I did reflect on the cycle leading to the targets for the next phase. My rational in this cycle is: With the old teaching method, the teacher would normally chew the text thoroughly and then feed the students with what s/he has chewed. Thus, the students' own ability to chew and digest has been handicapped. When they become accustomed to this way of learning, they will expect the teacher to tell them everything without being able to team and think by themselves. Therefore, the first step in this action research is to change the traditional teaching method - the teacher-centered bottom-up way of teaching reading - by introducing to them the relevant reading theories, strategies and skills. The purpose of the second step is to encourage both cooperation between the students within a group and competition among different groups so as to make the class active and the reading activities easy and enjoyable. In Step Three, activities and tasks are designed to train students to master both bottom-up and top-down reading skills. The last step, which is by no means the least and must be announced at the very beginning of the semester, is the new way of assessment which emphasizes their performance in the course of learning and hence encourages them to take an active part in the activities designed.

After reviewing my teaching diary and analyzing the data I collected from the interviews, I found there are two problems which arose from this cycle. The first problem is my students seemed to feel averse to group tasks assigned to them. As I said before, they have become accustomed to teacher-centered way of learning, they will expect the teacher to tell them everything without being able to team and think by themselves. This is one of the reasons they don't want to keep up with the designed activities. I should give them some time to adapt to the new teaching style instead of feeling disappointment by them. Another reason is from myself. I did my research to fast and gave too many tasks to my students. I need to modify my action research in cycle 3.

\section{Cycle 3: Maintaining and Protecting Motivation}

Week 9-12

Considering the problems in cycle 2, I planned action for maintaining and protecting students' motivation in English reading. In this cycle, I chose to use the new Instructional Technologies because of their pedagogical potential. The tasks which I assigned to students should be specified and clearer. For instance, I just asked students to take along one article they like reading to the class in cycle 2 . Instead of that, in cycle 3, I asked students to read the material with certain goals in the preparation step of each unit. That narrowed the reading materials they should read; also, it therefore made them read actively instead of passively. The details can be seen below.

\section{Before the class}

Before the class, I listed some tasks of material collection on certain topics, such as the things about growing up, what happened when you grow up, the people who affect you during your growing up, etc. Apart from these tasks, there were also some other tasks which deal with several key words and phrases that might be obstacles in understanding the text. The students were free to choose any of the listed tasks according to their interest. As a result, students were divided into groups according to different tasks he or she chose to collect material including text and pictures about it either on the Internet or in the library. Students had to read the material on the Internet and had to decide what the necessary information was. Then they collected the material together and edited the material. I gave them some help about how to explore on the Internet and how to find the useful information in the library. Each group of students discussed and negotiated with each other to finish the material collection. Before the class, the material each group collected were all sent to my email box so that I could organized the material in order to make a multimedia presentation in the class.

\section{In the class}

Step 1: warm-up

In the class, the multimedia presentation was done with the help of a computer. After the presentation, the students were given chances to make further explanations and discuss the topic.

\section{Step 2: Predict}

After the discussion, the students were given the title and the first paragraph of the text according to which students predicted the general idea of the text.

Step 3: Read

Then the students, with the prediction, read the text and recorded the time taken.

\section{Step 4: Discuss}

After the students finished reading the text, they discussed the general idea with each other. A discussion on some specific questions based on the text was also held afterwards. The discussion made the students reread the text and helped them understand the text better.

\section{Step 5: Analyze}

Whereafter, the text was analyzed paragraph by paragraph including the language points and rhetoric matters. Some meanings of the new words and expressions could be guessed by the students from the context. The students and I dealt with the usage of these words and expressions together. Finally, we worked out an outline of the text. 
In the following weeks of this cycle, I kept to this way of English teaching

In this cycle, I encourage the students to have constant contact with me through e-mail in English. I had students writing to me about learning difficulties and administration. I encouraged them to set their own goal in learning English, both a short goal and a long goal.

I encouraged each student to make contact with a native speaker through WWW chat-lines or the ICQ international chat tool. They felt very excited about this way. I promoted self-confidence and autonomy by giving them ample choice for assignment titles.

The activity of "The News of the Week" still carried on, but I decided to limit the time from 15 minutes to 10 minutes. They did "News of the Week" very well now. I demonstrated the three steps of the revised version of this activity: first, read or retell the news; second, answer questions from other students; and finally, explain some useful expressions in the news. Groups worked in these four weeks did a better job than the previous groups. I think it was all because the students were most interested in this activity, so they liked to devote their time and efforts in it. This was probably as a sage has put it---"interest is the best teacher."

For social culture input, from week 9, I gave my students 2 extra hours every Monday evening. I did an introduction to Hollywood films and western music. The only problem about this activity was that it was not in my working time. However, students showed strong enthusiasm in this way. And no doubt, in this way, students' integrative motivation was improved.

At the same time, I tried to increase the attractiveness of the course content. As I designed in my action plan of this cycle, I provided a point of entry before reading a new article. I picked a scene from a story, or an illustration or any paragraph or even page to be looked at or read in class before the actual reading. I tried to let the material to be accessible to the students and sufficiently stimulating to arouse interest and motivate them and give them a flavor of the work in terms of setting, characters, and narration etc. I encouraged pupils to predict what the story would be about or express a reaction (positive or negative) to the material.

At the end of week 11, one of my classes- the sampling, the students organized a mini English speech competition and invited me as their judge. I was very pleased to do this job. More autonomy, higher motivation. They showed their autonomy to learn English, which reflected their motivation in English learning.

During these four weeks, the activities I designed went smoothly and students agreed that we should continue with them. They said though they had to put more effort and time, the activities did improve their English very much. They also felt excited about using the new Instructional Technology.

I asked for my students' feedback at the end of this cycle. Some of the feedback was as I anticipated. Most students said they were motivated by the "learner-centered" way to learn. And they thought the class and the way of learning was effective. Of course, they also gave some suggestions, such as "role-play" and "video watching". In this cycle, I mainly used teacher logs, informal student interviews, Chongqing Jiaotong university Evaluation system on Internet (http://www.cqjtu.edu.cn) and colleague's observation to collect data. Students showed more involvement in the class activities. The time spent on their unsolicited behaviors were more than before. Here are some comments from my students:

- I feel the class is more active than before, and thanks to my teacher changing the dull atmosphere.

- The reading materials are so interesting and I like to "be lost in books"!

- My reading desire is rising than ever before. After watching movies, I like to find the original novel to read and learn more about the western society culture.

- The four actives you asked us to do have really improved my reading ability, enhance my vocabulary and made me to read more after class. Thank you!

- I like your Intensive Reading Class. It gave me a chance to share what I read with my class.

- I feel I got involvement in the reading section now. Also, I like group work. That make me more motivate to learn.

I reflected on my action in this cycle. After I did some changes on the basis of cycle 2, the group working obviously had great improvements. The results seemed to be satisfactory as the result showed above, but some problems still arose in this cycle. The phenomenon discovered by my colleague that some students didn't participate in the group work in this cycle drew my attention. I realized that there were more or less some students who at times didn't do the task assigned. And I also found that some students would never do anything unless the assignment was to be checked or graded. Even more, I found that a few students didn't prepare the material well. Some of them were very lazy and were always waiting for the other group members to collect material. Some students suggested that the group work of material collection should be graded and be given rewards. I took them along to the last cycle.

\section{Cycle 4: Rounding off the learning experiences}

\section{Week 13-16}

In these four weeks, the English class remained the same except for some changes which were made according to my students' feedback and my reflection. The students' group work of material collection was evaluated after the presentation by the students and I together. The best group was given awards such as notebooks. Accordingly, the group who did the worst job made a presentation in the class on the topic which they chose. This way turned out to be effective. The students all enthusiastically collected material. Apart from that, Role-plays, English films, and more background knowledge were added in the class. Given most of my students are interested in music according to their 
self-introduction, I also taught them some English songs and introduced them to some English singers. During the activities, not only did my students do English reading but also their English speaking and listening were practiced. From then on, I really understood the importance about Increasing Learner Satisfaction and the Question of Rewards and Grades!

I reflected on my fourth cycle, though students showed much enthusiasm on reading class now, one problem still arose from this cycle, actually, it took me to considering my further study. In general, motivation can be considered as either intrinsic (behavioral, needs) or extrinsic (cognitive and humanistic, reinforcement). Intrinsic motivation is generally possessed by people having a persona interest or interests in doing something and helping to set their goals. People are intrinsically motivated not because of accomplishing the activity they do brings a reward, but because doing the activity itself is a reward. Although increasing learner satisfaction and rewards in class played an important role to motivate my students, the basic question is to improve their intrinsic motivation.

At week 16, in order to know the students reactions to the 16 weeks action plan, the second questionnaire-Questionnaire 2 was designed and distributed to the students. Part I of Questionnaire 2 is the same with Part I of Questionnaire 1. 56 questionnaires were distributed to the students and all of them were collected.

\section{RESULT}

Below is the analysis on the students' response to Questionnaire 2.

TABLE 1:

\begin{tabular}{|l|l|l|l|l|l|l|l|l|l|l|l|l|l|l|l|}
\hline Statement & $\mathbf{1}$ & $\mathbf{2}$ & $\mathbf{3}$ & $\mathbf{4}$ & $\mathbf{5}$ & $\mathbf{6}$ & $\mathbf{7}$ & $\mathbf{8}$ & $\mathbf{9}$ & $\mathbf{1 0}$ & $\mathbf{1 1}$ & 12 & $\mathbf{1 3}$ & $\mathbf{1 4}$ & $\mathbf{1 5}$ \\
\hline $\begin{array}{l}\text { Average } \\
\text { Point of Q1 }\end{array}$ & $\mathbf{4 . 5}$ & $\mathbf{4 . 7}$ & $\mathbf{3 . 8}$ & $\mathbf{5 . 1}$ & $\mathbf{5 . 7}$ & $\mathbf{5 . 0}$ & $\mathbf{3 . 6}$ & $\mathbf{5 . 4}$ & $\mathbf{6 . 2}$ & $\mathbf{3 . 7}$ & $\mathbf{4 . 1}$ & $\mathbf{4 . 8}$ & $\mathbf{4 . 0}$ & $\mathbf{6 . 6}$ & $\mathbf{5 . 9}$ \\
\hline $\begin{array}{l}\text { Average } \\
\text { Point of Q2 }\end{array}$ & $\mathbf{6 . 1}$ & $\mathbf{5 . 7}$ & $\mathbf{5 . 7}$ & $\mathbf{5 . 6}$ & $\mathbf{6 . 7}$ & $\mathbf{6 . 4}$ & $\mathbf{5 . 5}$ & $\mathbf{6 . 2}$ & $\mathbf{6 . 8}$ & $\mathbf{5 . 9}$ & $\mathbf{5 . 9}$ & $\mathbf{4 . 9}$ & $\mathbf{4 . 0}$ & $\mathbf{5 . 8}$ & $\mathbf{5 . 0}$ \\
\hline
\end{tabular}

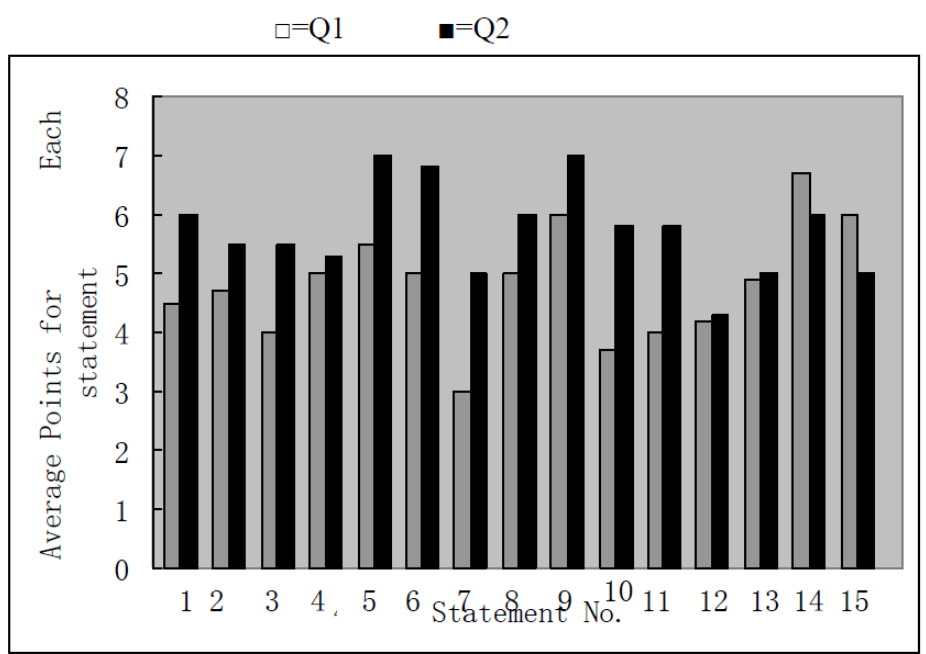

Figure 1: Comparison of the Average Points of Each Statement in Part I between Q1 and Q2

From Table 1 and Figure 1 we can see that the average points of statements 1-11 in Q2 are all on the positive side of the scale above 5.0, and are all higher than that in Q1, especially between statements 1, 3, 7, 10 and 11 . This result shows that the implementation of the 16-week action plan leads to the following results:

1. They found the class more intellectually challenging and stimulating;

2. They felt they had learned something more valuable;

3. They had more interest in English reading;

4. They had learned and understood the subject materials of this course better;

5. The teacher was more enthusiastic about teaching the class;

6 . The teacher was more dynamic and energetic in conducting the class;

7. The teacher's style of presentation was more attractive;

8. The teacher's explanations were clearer;

9. Class materials were prepared and explained more carefully;

10. Students were encouraged more to participate in class discussions.

11. Students were encouraged more to express their own ideas and/or question the teacher.

The average points in Q2 for statement 12 and 13 remained unchanged, which shows that the students still think that the texts they are learning are difficult and not very interesting.

The average points in Q2 for statement 14 and 15 become lower than that in Q 1 and are around the neutral point on the scale, which means that the students think the supplementary materials are more helpful also more reading strategies 
and skills are taught during the implementation of the 16-week action plan.

Part III of Q2 had five open questions. The students' answers to these questions are summarized as follows.

1 . Which of the above-mentioned improvements do you like best? Why?

39 out of the 53 respondents choose the "News of the Week" as their favorite activity, and the main reason is that they can learn more useful expressions.

2. What other improvements do you think should be made on the course of intensive reading?

Eight of the students think that I should explain the texts in more detail so that they can understand them better; three of the students suggest I should provide more examples of how the new words in the text can be used; eleven of the students hope that I can bring more supplementary materials to class.

3. What is your general impression on this course in the past 16 weeks?

35 students answered this question, twenty-nine of whom feel that my way of teaching has greatly improved, however the texts were too difficult; the other students thought that the supplementary materials were very helpful and my lesson could be made more interesting and attractive.

4. Please make your free comment on my work or on this course.

All the 53 students who answered the question were very satisfied with my teaching. They said that no other teachers would be so critical with their teaching, and no other teachers would spend so much time on the preparation of the lesson. They acknowledged that they had learned not only a lot of new words and valuable information, but also the work ethic of a responsible teacher.

TABLE TWO:

RESULTS OF TWO TESTS BEFORE AND AFTER THE ACTION RESEARCH

\begin{tabular}{|lllllllll|}
\hline $\begin{array}{l}\text { Student } \\
\text { number }\end{array}$ & Read 1 & Cloze1 & Test1 & Read2 & Cloze2 & Test2 & Time1 & Time2 \\
\hline Average & 54.29 & 55.80 & 55.04 & 66.96 & 69.82 & 68.39 & 72.46 & 49.38 \\
\hline
\end{tabular}

Read 1 and read2 - the result of the reading comprehension in the tests taken before and after the action research respectively

Cloze 1 and Cloze2 - the result of the cloze tests taken before and after the action research

Test 1 and Test $2(\%)$ - the result of the tests taken before and after the action research

Time1 and Time2 (minutes) - time taken in the tests before and after the action research

Average - the average results of the whole class

The table includes the average results and some students' results of the tests. From the table, we can see that there is significant progress both in the reading comprehension and cloze tests. It is obvious that the time taken in the second test is much shorter than that of the first test. Most students' reading speed and reading comprehension improved after the action research. However, we can't say their English reading ability is improved only because their motivation is increased. But anyway the results of the test give us references on the effect of using motivational strategies in an Intensive Reading class.

\section{DISCUSSION}

\section{A. Achievements}

The data collected in the first cycle suggested: most students have strong motivation in English learning.

The data also showed most students have much stronger instrumental motivation than integrative motivation. However, those who have stronger integrative motivation, where found to be stronger in their reading ability as well.

This conclusion is in accordance with Christine Nuttal's opinion. Nuttal thought weak readers were in a vicious circle. Wherever a reader comes, any factor could result in other factors. For instance, student who read slower hardly enjoy reading; they couldn't enjoy reading, so that they read as few as he could; they read few, so that they has difficulty in reading, therefore, their reading speed is slow. Nuttal explained it as the following cycle:

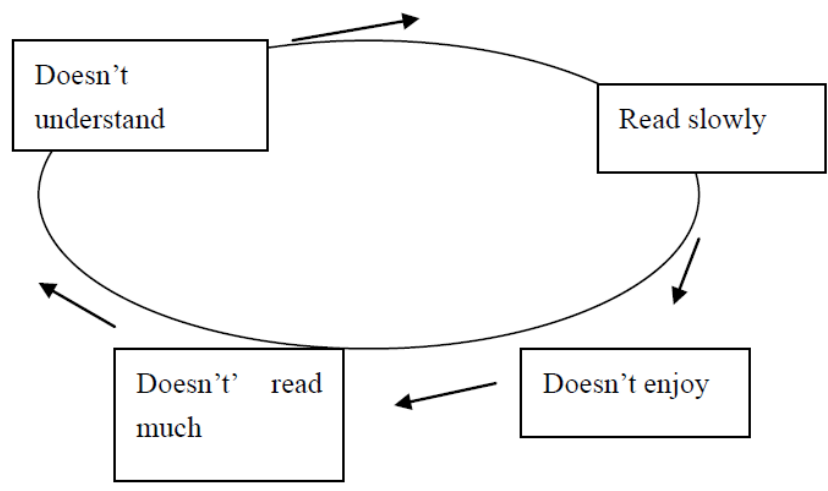

The vicious circle of the weak reader (Nuttal. C. 1983, 167) 
Moreover, Nuttal supposed that if students want to get out of the vicious circle and get into the virtuous circle, they have to enjoy reading and read much.

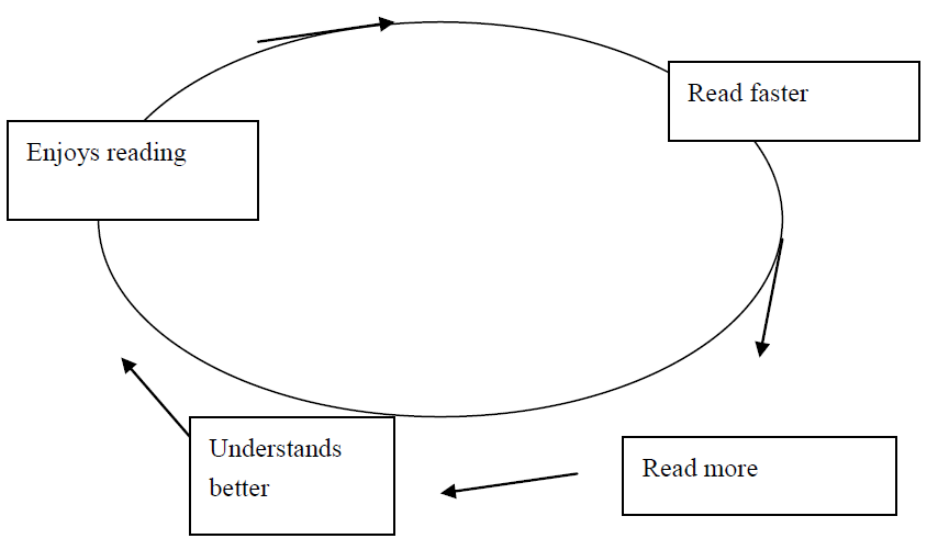

The virtuous circle of the good read ( Nuttal. C, 1983, 167)

I reflected on the result of my action research. The first research questions can be answered. Firstly, students have strong motivation for English reading, and most of them have stronger instrumental motivation like for passing examinations, getting information and for their future jobs. So that the text books authors should consider the students needs. Many students do their homework and engage in many types of learning activities, even when a subject is not very interesting. Obviously, these students share the belief of the curriculum makers that what they are being taught will come in handy. In order to inspire learners to concern themselves with most learning activities, we should find out their goals and the topics they want to learn, and try to incorporate them into the curriculum. We should supply more teaching activities with high efficiency which can be suitable for the teaching materials. Secondly, students who have stronger integrative motivation also have stronger reading ability. This phenomenon shows that one of the effective ways to improve English reading is to cultivate students' integrative motivation. The teaching materials therefore should be interesting. Dornyei (2001) suggested using Popular culture to increase students' motivation. In my action research, I used the Internet, multiple media facilities to play western movies and introduce the songs from western society. Obviously, this is an effective way. But the problem is that there are only 8 teaching times for Intensive Reading Class and a movie should at least use 2 and half teaching times. So I played the movies for my students every Monday evening. The time is not included in out teaching time. How to solve this problem and keep a balance between my spare time and working time is a question that needs to be considered in the future.

\section{B. Problems Arising from the Research}

Although most of the results confirm the aspects of the research literature and my own assumptions, there are two problems that arose from my action research which seem to be different from my assumption.

The phenomenon discovered by my colleague that some students didn't participate in the group work in cycle one drew my attention. I realized that there were more or less some students who at times didn't do the task assigned. And I also found that some students would never do anything unless the assignment was to be checked or graded. The result is that these students actively participated in the class, but they would still not do the assignments if they were not required to be handed in.

Another phenomenon that appeared in cycle two demonstrated this problem once again. Some students forgot the lessons very fast because they never reviewed the lesson after class. Some students on one hand actively participated in the tasks which were assigned by the teacher and enthusiastically participated in the in-class discussion, on the other hand they were not active learners after class to some extent. Although in cycle three of my action research, I addressed this problem to a certain extent by assigning compositions to them, I still feel this problem hasn't been completely resolved. The two phenomena show that some students didn't learn by themselves but learn under the teacher's inspection.

The teacher cannot force the students to learn. The learning should be active and class should be student-centered. Learning should be completed by the acquisition of knowledge construction by the learner him or herself. In my action research, I tried to make my English class more interesting through different ways in order to make my students learn actively. Nevertheless, some students seemed unaffected.

The issue may result from several reasons. The first reason is connected to my students' habit of depending on the teacher to tell them everything they should do. This habit is very common in high school. The conventional teaching style in China is teacher-centered. The teacher decides every thing in the class. Because the test scores are almost the only standard which can decide whether the students can enter university and what kind of university the students can go to, high school teachers and students pay too much attention to the test scores. That results in the students' learning for high scores. They do not learn actively but often passively. In the long run, the students lose their ability of independent study and get into the habit of depending on the teacher. Entering university, many students face the fact 
that nobody will tell them what they should do after class and how. Some students soon adapt themselves to the new situation. Some would do nothing because they think nobody has asked them to do anything. For this kind of students, the best way is to help them in developing good learning habits.

The second reason may relate to the students' instrumental motivation in English learning. I know some students who in the first class declared they had little interest in English learning. It may root from the learning and teaching styles in high school. In the teacher-centered classroom, the students' aim of English learning changed into high score but not learning knowledge itself. Therefore large amount of training for the test was taken. This kind of learning can hardly be interesting. Therefore some students lost the interest in learning. By various means, some of my students' interest in English reading had been promoted. However, in EFL learning context, there were still few students who were not affected by those means. Therefore, promoting students' English integrative motivation is a complex and long-term work. This is also an issue needing further research.

The final issue is about reward and evaluation. The feeling of satisfaction is a significant factor in reinforcing achievement behavior, which renders satisfaction a major component of motivation. Students gave suggestions in cycle 3 and they asked graded their performance, which prove the significant of rewards and evaluation. In other words, grades focus on performance outcomes, rather than on the process of learning itself. Consequently, 'many students are grade driven, not to say, "grade grubbing," and this preoccupation begins surprisingly early in life' (Covington, 1999, 127).

\section{REFERENCES}

[1] Alison, J. (1993). Not bothered? Motivating reluctant language learners in Key Stage 4: London: CILT.

[2] Argyle, M. (1969). Social Interaction. London: Tavistock Press.

[3] Benson, P. (2000). Teaching and researching autonomy in language learning. London: Longman.

[4] Chambers, G. N. (1999). Motivating language learners. Clevedon: Multilingual Matters.

[5] Covington, M. (1999). Caring about learning: The nature and nurturing of subjectmatter appreciation. Educational Psychologist, 34: 127-36.

[6] Daniels, R. (1994). Motivational mediators of cooperative learning. Psychological Reports, 74: 1011-22.

[7] Dornyei, Z. and Otto, I. (1998). Motivation in action: A process model of L2 motivation. Working Papers in Applied Linguistics (London: Thames Valley University), 4: 43-69.

[8] Dornyei, Z. (2001). Teaching and Researching Motivation. England: Pearson Education Limited.

[9] Ehrman, M. E. and Dornyei, Z. (1998). Interpersonal dynamics in second language Education: The visible and invisible classroom. Thousand Oaks, CA: Sage.

[10] Good, T. L. and Brophy, J. E. (1994). Looking in classrooms. 6th edition. New York: HarperCollins.

[11] Little, D. (1991). Learner autonomy 1: Definitions, issues and problems. Dublin: Authentik.

[12] MacIntyre, P. D. (1999). Language anxiety: A review of the research for language Teachers. In Young, D. J. (ed.). Affect in foreign language and second language learning. Boston, MA: McGraw-Hill, pp. 24-45.

[13] Qiufang Wen. (2001) A study between the Individual Difference and English Learning Strategies of Non-English Major in College. English Language Learning and Teaching, Beijing:23-25

[14] Rogers, C. (1991). On becoming a person. Boston, MA: Houghton Mifflin.

[15] Ushioda, E. (1997). The role of motivational thinking in autonomous language Learning. In Little, D. and Voss, B. (Eds.). Language centres: Planning for the new millennium. Plymouth: University of Plymouth, CERCLES, Centre for Modern Languages, pp. 39-50.

[16] Wenden, A. (1991). Learner strategies for learner autonomy. Hemel Hempstead: Prentice Hall.

[17] Wright, T. (1987). Roles of Teachers \& Learners. Oxford: Oxford University Press.

Xiao Fu was born in Chongqing, China in 1978. She has received her Master Degree from University of Strathclyde, Scotland in 2003. She is currently a Lecturer in College of Foreign Languages, Chongqing Jiaotong University, China. Her research interests include English teaching methods and English literature. 